\title{
Using PCR for detection of Borrelia sp. in Ticks and Ruminants in Egyptian Desert
}

Sayed M.M. Abdel-Baky¹, Nesreen A.T. Allam², Yasser M. Kamel ${ }^{3}$, Amani A. Hafez ${ }^{3}$

${ }^{1}$ Parasitology Unit, Department of Animal Health, Division of Animal and Poultry Production, Desert Research Center, Matariya, Cairo, P.O. Box: 11562, Egypt

2 Parasitology and Animal Diseases Department, Veterinary Research Division, National Research Centre, P.O. Box: 12622, Dokki, Egypt

${ }^{3}$ Infectious Diseases Unit, Department of Animal Health, Division of Animal and Poultry Production, Desert Research Center, Matariya, Cairo, P.O. Box: 11562, Egypt

\section{ARTICLE HISTORY}

Received: 16.08 .2020

Revised: 25.10 .2020

Accepted: 30.10 .2020

Address correspondences to Amani hafez; Tel. +201222203735, Email:amani.hafez@yahoo.com, ORCID 0000-0003-2793-7859

\section{ABSTRACT}

\begin{abstract}
Objective: To investigate the prevalence of Borrelia burgdorferi infection in ticks and ruminant hosts. Design: Cross sectional study.

Animals: 739 Ixodes ticks, 110 camels, 120 sheep and 40 cattle.

Procedures: All collected samples were tested by using nested PCR technique (nPCR) using OspA and flaB gene as the targets.

Results: Out of 739 adult Ixodes ticks, $111(15 \%)$ were infected, the highest rate was in $A$. variegatum (43.24\%) followed by $A$. lepidum (30.63\%) and B. annulatus (26.13\%). Shalatten was the most infected locality (18.52\%) followed by Dakhla Oasis and Bir El-Abid in ratio $18.52 \%$ and $16.05 \%$, respectively. Camel was the most infected animal (40.74\%), then sheep $(37.04 \%)$ and cattle $(22.22 \%)$.

Conclusion and Clinical relevance: Medical and veterinary professionals in Egypt should consider $B$. burgdorferi as an emerging pathogen in the country. Future studies are needed to monitoring vertorial capacity of ticks in transmission $B$. burgdorferi to animals in parallel with discovering other reservoir host animals and the vector competence of tick species for $B$. burgdorferi and its public health and economic significance in Egypt.
\end{abstract}

Keywords: Borrelia burgdorferi, Borreliosis, nPCR, Ixodes ticks

\section{INTRODUCTION}

In the late twentieth century, the importance of infectious diseases has been increased. More than $25 \%$ of annual deaths worldwide are estimated to be directly attributed to the emergence and resurgence of infectious diseases [1].Ticks are obligate hematophagous ectoparasite of vertebrates that have a limited mobility, but can be transported over large geographical distances by wild and domestic mammals and birds. Besides causing direct damage associated with blood feeding, they considered as the mainly vital vector in transmitting a great variety of pathogens, including bacteria, virus, protozoa andhelminthsthat cause mild to lethal diseases in man and animals [2, 3]. From these pathogens, Borrelia spp. and Coxiella spp.

Borrelia spp. are best studied tick-borne pathogens. These spirochetes are motile Gram-negative, helical-shaped bacteria. Structurally, it is composed of inner and outer cell membranes, with 7-11 flagella located between them. The outer membrane comprises a varity of outer surface proteins (Osp) whichare thought to be responsible for adaptation and survival of thespirochete in vector and host tissues. Flagellin is additional antigenicstructures of Borrelia burgdorferi, which is considered themain component of flagella, in addition to, 60-kDa common antigen, which is a member of the heat-shock protein family [4].
Borreliaspp are conserved in nature through complex interactions among ticks, particularly Ixodes spp., and a range of vertebrate hosts. They classified within the phylum spirochetes that embrace two major groups $[5,6]$. The first is the Lyme borreliosis (Borreliaburgdorferisensulato), are transmitted by hard ticks (Ixodidae). The second group contains several Borrelia relapsing fever (RF) species, with the exception of $B$. recurrentis (louse-borne RF spirochetes), are transmitted via soft ticks (Argasidae).

Therefore, this study was designed to investigate the isolation, characterization, and incidence of Borreliaspp. in both Ixodes spp. ticks and ruminant livestock in different biocenosesof Egypt.

\section{MATERIALS AND METHODS}

\subsection{Ethical considerations}

The protocol was in accordance with the ARRIVE guidelines and the EU Directive 2010/63/ EU for animal testing and the NIH Manual for the Care and Use of Laboratory Animals (NIH Publications No. 8023 revised 1978). Moreover, it was agreed with the ethical guidelines approved by the Ministry of Higher Education and Scientific Research (50/4/10), National Research Center (10120507). The collection of ticks on ruminants did not involve national farms or other protected areas or endangered or protected species. 


\subsection{Study regions and animals}

Between June 2014 and April 2016, Ixodid ticks were collected from 270 ruminnants (120 sheep, 110 camels, and 40 cattle) in twelve localities from nine regions in Egypt, as shown in Figure 1. All the ticks were collected, either by hand or with pair of forceps[7], and taken to the laboratory for study.

\subsection{Tick identification}

All collected hard ticks were transferred to the laboratory where they were categorized and enumerated under magnification. Ticks were identified to the species level using previously established taxonomic identification keys for adults [8]. All the needed information about the collected ticks were organized to be on the tube as genera, species, host and animal number, collection site and date.

\subsection{Tick processing}

The identified adult ticks were dissected to remove the distal portion of the legs for getting the hemolymph. The rest of the tick was longitudinally cut in two equal parts. One part for molecular biology, and the other was preserved frozen at $-80^{\circ} \mathrm{C}$ as a backup sample for any additional analysis. Ticks were pooled together by species and separated into groups of up to five adult ticks per pool for testing.

\subsection{Detection of the pathogen in blood and hemolymphsamles}

Hemolymph was bled directly on a glass slide and left to dry for 20-30 minutes. The glass adhered hemocytes were fixed in air for 15-20 min. Animal blood and tick hemolymph were stained with Fontana stain [9]. Stained smears were investigated microscopically for the presence of Borrelia spp.

\subsection{DNA extraction, molecular detection and sequencing}

The QIAamp DNA Mini Kit (Qiagen, Valencia, CA, USA) was employed according to the manufacturer's instructions to extract the genomic DNA from collected animal blood samples and tick pools in each species. DNA concentration was estimated using a Nanodrop 2000 Spectrophotometer (Thermo Fisher Scientific, Waltham, MA).

DNA samples were analyzed for the presence of $B$. burgdorferisensustricto by nested PCR technique (nPCR) to increase the specificity. The first round of PCR to detect Borrelia-specific loci. Then, the product will be used as a new template to create internal amplified smaller fragment. Two Borrelia genes were subjected to amplification. Flagellin $B$ (FlaB) which encodes flagellum major protein [10], and located on the linear chromosome, while the other gene was Outer surface protein $A(\operatorname{OspA})$ that responsible for tick midgut colonization, and is plasmid-encoded [11, 12].

The nested PCR was subjected to determine theBorreliaspp. via amplification of 5S-23S rRNA Intergenic
Spacer Region and the flagellin gene $(f l a B)$. The sequence of the primers is shown in Table 1.

Reaction conditions for the tesed genes were as follows: $95{ }^{\circ} \mathrm{C}$ for $5 \mathrm{~min} ; 40$ cycles of $95{ }^{\circ} \mathrm{C}$ for $15 \mathrm{~s}$, annealing temperature for $30 \mathrm{~s}, 72{ }^{\circ} \mathrm{C}$ for $45 \mathrm{~s} ; 72{ }^{\circ} \mathrm{C}$ for $5 \mathrm{~min}$; and hold at $4{ }^{\circ} \mathrm{C}$. The annealing temperatures were different and shown in detail in table (1). The investigated samples were considered positive for Borrelia burgdorferi when the inner amplicons were detected on agarose gel electrophoresis from both Borrelia genes.

DNA sequencing and capillary electrophoresis were implemented for both strands (in both directions) of the PCR amplicons according the protocol previously published [13]. The same primers applied for the initial PCR amplification were used. Final sequence analysis and editing was performed by using Sequencer 4.7. Using BLASTN, version 2.2.10 (www.ncbi.nlm.nih.gov/blast/Blast.cgi), edited sequence data was compared with genetic sequences from characterized examples of Borrelia spp. published in GenBank.

\subsection{Statistical Analysis}

The number homogeneity of collected ticks was tested by the Chi-square depending on infected hosts with Borrelia burgdorferi in different localities and different infected Ixodid ticks that by using the FREQ Procedure Model of SAS [14]. The permitted method was applied consistent with Snedecor and Cochran [15]. Probability values (P-value) were judged statistically significant at $<0.05,0.01$ and $<0.001$.

\section{RESULTS}

\subsection{Microscopical detection of Borrelia spp. in stained smears}

Spirochetes were not seen in any direct stained animal blood samples. However, the Fontana stain succeded in detection of Borrelia spp. in hemolymph smears. So, prevalence of Borrelia spp. in animal hosts according to Fontana stain result was zero\%, whereas their ticks species yield $3 \%$. This result strengthens the value of the PCR-based technique in the detection of Borrelia spp. Figure (1) from arthropod and mammalian specimens.

\subsection{Molecular detection of Borrelia spp.}

As represented in Figure 2, the BorreliaFlaB and OspA genes loci were targeted for detection of the Borrelia burgdorferi bacteria through nPCR technique. The FlaB and OspA products from each tick were reported and compared against controls via gel electrophoresis. The FlaB primers (The amplicon appeared at 447 bp) capture $B$. burgdorferi s.s. and other closely related Borrelia geno species, while OspA primers (the amplicon appeared at $350 \mathrm{bp}$ ) detect only $B$. burgdorferi s.l. Amplification from both loci would indicate the presence of $B$. burgdorferi. s.l. 
Table1. Sequence of Borrelia Species-Specific Genes usedduringnPCRAmplifications.

\begin{tabular}{|c|c|c|c|c|}
\hline Primer & Target gene & $5^{\prime}$-Sequence-3' & $\begin{array}{l}\text { Amplicon } \\
\text { size (bP) }\end{array}$ & $\begin{array}{l}\text { Annealing } \\
\text { Temp. }\end{array}$ \\
\hline $\begin{array}{l}\text { FlaB1-Fw } \\
\text { FlaB1-Rv }\end{array}$ & \multirow{2}{*}{$\begin{array}{l}\text { Flagellin gene } \\
\text { (flaB) }\end{array}$} & $\begin{array}{l}\text { GCATCACTTTCAGGGTCTCA } \\
\text { TGGGGAACTTGATTAGCCTG }\end{array}$ & 503 & $55^{\circ} \mathrm{C}$ \\
\hline FlaB2-Fw FlaB2-Rv & & $\begin{array}{l}\text { CTTTAAGAGTTCATGTTGGAG } \\
\text { TCATTGCCATTGCAGATTGT }\end{array}$ & 447 & $58^{\circ} \mathrm{C}$ \\
\hline OspA1-Fw OspA1-Rv & \multirow{2}{*}{$\begin{array}{l}\text { Outer surface } \\
\text { protein A } \\
\text { (OspA) }\end{array}$} & $\begin{array}{l}\text { CTTGAAGTTTTCAAAGAAGAT } \\
\text { CAACTGCTGACCCCTCTAAT }\end{array}$ & 487 & $55^{\circ} \mathrm{C}$ \\
\hline $\begin{array}{l}\text { OspA2- Fw } \\
\text { OspA2- Rv }\end{array}$ & & $\begin{array}{l}\text { ACAAGAGCAGACGGAACCAG } \\
\text { TTGGTGCCATTTGAGTCGTA }\end{array}$ & 350 & $58^{\circ} \mathrm{C}$ \\
\hline
\end{tabular}

Table 3. Incidence of Borrelia spp. within species of Ixodes ticks in the investigated localities in Egypt.

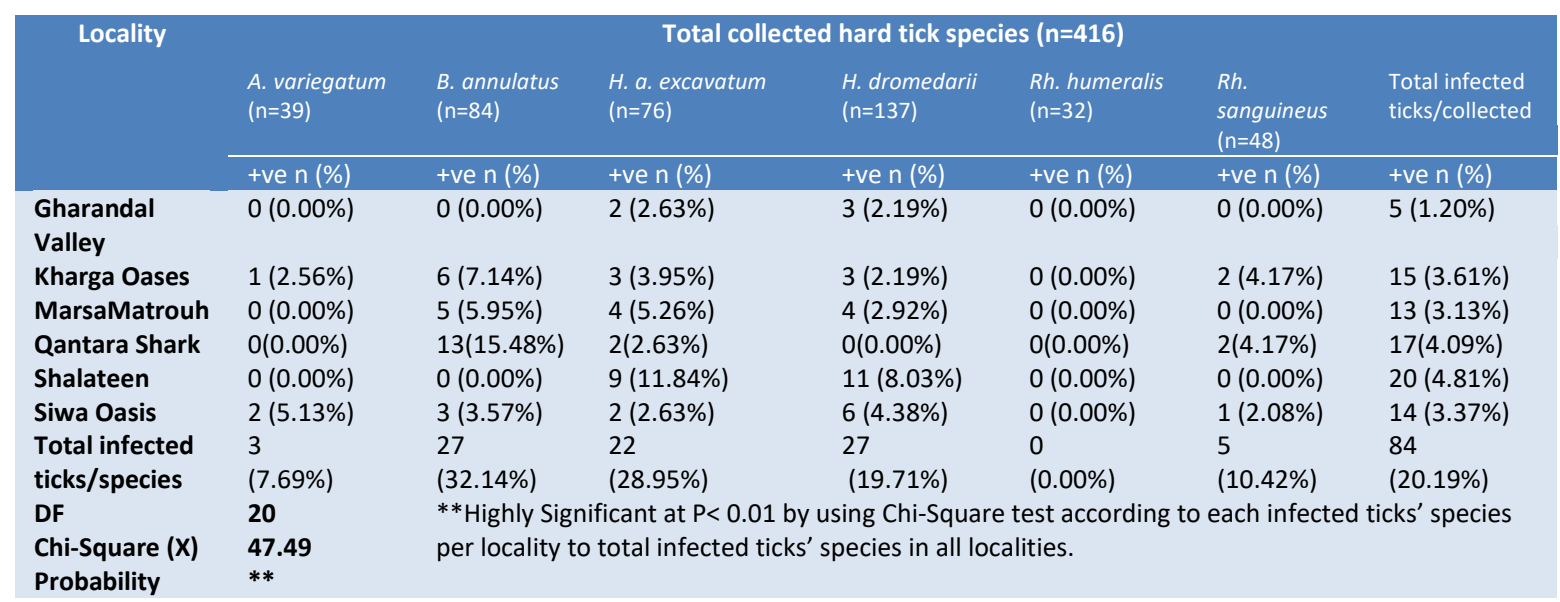

Table 3. Incidence of Borrelia spp. within ruminants in the investigated localities in Egypt.

\begin{tabular}{|c|c|c|c|c|c|c|c|c|}
\hline \multirow[t]{3}{*}{ Locality } & \multicolumn{2}{|c|}{ Camel } & \multicolumn{2}{|c|}{ Cattle } & \multicolumn{2}{|c|}{ Sheep } & \multicolumn{2}{|c|}{$\begin{array}{c}\text { Total infected } \\
\text { animals/examined }\end{array}$} \\
\hline & \multirow[t]{2}{*}{ Ex. No } & infected & \multirow[t]{2}{*}{ Ex. No } & infected & \multirow[t]{2}{*}{ Ex. No } & \multirow{2}{*}{$\frac{\text { infected }}{\text { No. (\%) }}$} & \multirow[t]{2}{*}{ Ex. No } & infected \\
\hline & & No. (\%) & & No. (\%) & & & & No. (\%) \\
\hline Gharandal Valley & 17 & $1(5.88 \%)$ & 0 & $0(0.00 \%)$ & 5 & $0(0.00 \%)$ & 22 & $1(4.55 \%)$ \\
\hline Kharga Oasis & 11 & $2(18.18 \%)$ & 28 & $7(25.00 \%)$ & 7 & $0(0.00 \%)$ & 46 & $9(19.57 \%)$ \\
\hline MarsaMatrouh & 20 & $3(15.00 \%)$ & 7 & $2(28.57 \%)$ & 61 & $5(8.20 \%)$ & 88 & $10(11.36 \%)$ \\
\hline Qantara Shark & 11 & $1(9.09 \%)$ & 33 & $12(36.36 \%)$ & 11 & $0(0.00 \%)$ & 55 & 13 (23.64\%) \\
\hline Shalateen & 58 & $36(62 \%)$ & 0 & $0(0.00 \%)$ & 63 & $8(12.70 \%)$ & 121 & 44 (36.4\%) \\
\hline Siwa Oasis & 18 & $1(5.56 \%)$ & 3 & $0(0.00 \%)$ & 21 & 7 (33.33\%) & 42 & $8(19.05 \%)$ \\
\hline Total examined & 135 & & 71 & & 168 & & 374 & \\
\hline Total infected & 44 & & 21 & & 20 & & 85 & \\
\hline ticks/species & (32.6\%) & & $(29.58 \%)$ & & $(11.90 \%$ & & $(22.7 \%)$ & \\
\hline DF & 10 & & EX. No. & $=$ Examined $\mathrm{n}$ & nber - & **Highly Sigr & cant at $\mathrm{P}$ & 0.01 by using Chi- \\
\hline Chi-Square (X) & 59.86 & & Square $t$ & st according $t$ & each inf & cted host per & cality to $t$ & otal infected hosts \\
\hline Prob. & $* *$ & & & & & & & in all localities. \\
\hline
\end{tabular}

\subsection{Prevalence of Borreliaburgdorferis.I in Ixodes ticks in different localities}

Hard ticks in the present study were collected from a total of 374 animals (168 sheep, 135 camels and 71 cattle) in six localities, as shown in Figure (1). A total of 416 Ixodes ticks, were collected and submitted to the laboratory for tick identification and Borrelia spp. detection. They are representing 6 tick species, Hyalomma dromedarii $(n=137)$, Hyalomma anatolicum excavatum ( $\mathrm{n}=76)$ Amblyomma variegatum $(n=39)$, Rhipicephalus sanguineus $(n=48)$, Rhipicephalus humeralis ( $\mathrm{n}=$
32), andBoophilusannulatus( $\mathrm{n}=84)$, as demonstrated in Table 2.

This study showed an overall frequency of ticks infection was $20.19 \%$ (84/416) of Borreliaspp. Of these infected ticks; $32.14 \%$ (27/84), 28.95\% (22/84), 19.71\% (27/84), 10.42\% (5/84) and $7.69 \%$ (3/84) were in Boophilus annulatus, Hyalommaa natolicumexcavatu, Hyalomma dromedarii, Rhipicephalus sanguineus, and Amblyomma variegate, $m$, respectively. The species, Rhipicephalus humeralis showed no infection.

Concerning the distribution of the infection, the most infected localities were Shalateen, QantaraSharq, Kharga oases, Siwa oasis, and Marsa Matrouh recording 4.81\%, 
$4.09 \%, 3.61 \%, 3.37 \%$, and $3.13 \%$, respectively. The lowest percentage of infection was recorded in Gharandal valley (1.2\%). Moreover, the camels were the most susceptible animal type to borreliosis (32.6\%) than other ruminants studied where cattle and sheep were recorded $29.58 \%$ and $11.9 \%$, respectively. The highest location of infection was in Shalateen (36.4\%) followed by QantaraSharq, Kharga oasis, Siwa oasis, MarsaMatrouh, and Gharandal valley with recorded percentage $23.64 \%, 19.57 \%, 19.05 \%, 11.36 \%$, and $4.55 \%$, respectively as shown in (Table 3 ).

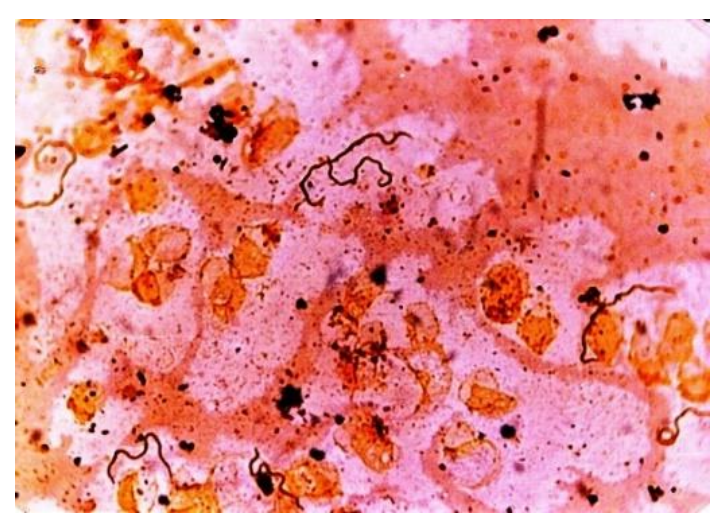

Figure 1. Borrelia spp. appeared stained with Fontana stain $(x=100)$

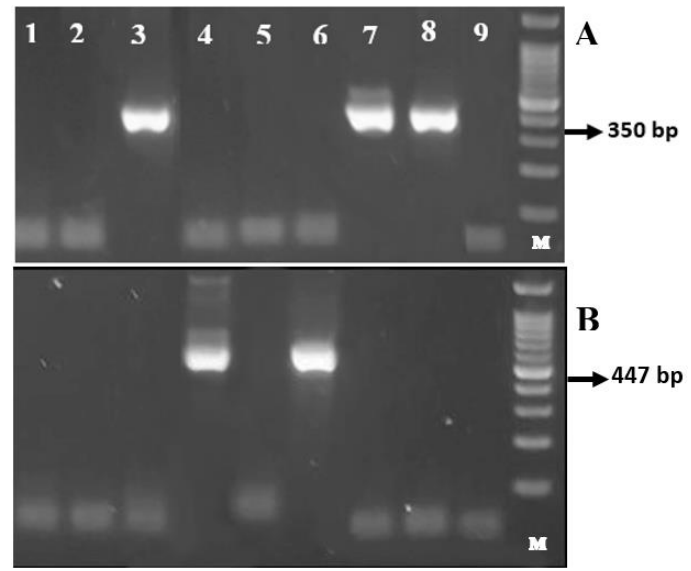

Figure 2. Molecular identification of Borreliaspp. by nPCR products of flab and ospAgenesdetected in $1.5 \%$ agarose gels stained with ethidium bromide.(A): Lane M:100bpDNAladder. Lane1:negative control and Lanes 3,7,8 positive samples at 350bpampliconof ospA gene (B):Lane M:100bpDNAladder. Lane1:negative control and Lanes 4,6 positive samples at 447 bpampliconofflaB gene.

\section{DISCUSSION}

The distribution data of tick-borne pathogens and their possibleassociation with emerging and distinct illnesses in Egypt are not extensively available. Animal who become diseased after a tick bite may be at increased risk of infection because the tick bite considered as the source of the pathogen.There is lacking in the detailed knowledge of the tick-borne pathogens, their distribution, and relationship to their vectors. Studies of pathogens carried in ticks in nondisease-knownendemicregions might provide epidemiological information about the pathogenic organisms, their vectors, and reservoirs. Moreover, these data might also deliver a chance to examine the causes of emerging zoonoses for which different factors for disease transmission may be present.

In this respect, despite the arlier detection of Borreliaspp. in Egypt since 2010 by using PCR reaction [16], little is known about their epidemiology and detrimental effect on animals and humans [17]. In the present study, our result revealed that camels were the most susceptible to borreliosis (32.6\%) than other animals studied. Shalateen has the highest infection rate (62\%) among examined camels where it comprises the main exported camel market in Egypt whereas thousands of camels imported from Sudan and other African countries. The importance of camels in that they are the main animals-structure in the Bedouin desert communities, therefore, camel grazing is the main activity practiced (shepherds) by the citizensat Eastern, Western and Southern Egyptian borders, and Sinai. So, they play an important and pivot role in the spread of ticks from one area to another as well as they serve as reservoir in transmitting the infection among the population of those areas and of course mainly to shepherds.

It is established that the cattle tick, $B$. annulatus is the main tick species infest cattle in Egypt [18] and it is considered the main vector of bovine borreliosis [19]. Our findings are in line with the previous published work that the highest infection rate of $B$. annulatus $(15.48 \%)$ was in Qantara Sharq where there are considerable count of cows and people depend on them in the field of agriculture and family income.

Unfortunately, In Egypt, data on Lyme disease are scarce, and there is no any study of Lyme disease in animals and ticks has been documented to verify its zoonotic evidence. In addition, no attemps were performed to isolate $B$. burgdorferi from clinical specimens [20]. While any level of prevalence may be worrisome, the current risk of lyme disease in the regions we investigated appears to be in concordance if compared with the previous published results in different areas in Egypt; Dahshore, Abu Rawash, Kerdasa, KafrTohormos, Saft el Laban and Nahia, Giza Governorate where the infection rate was between $0.0-50.0 \%$ ( $B$. annulatus 8\%; H.dormedarii 25\%; H.excavatum 50\%; R.sanguineus 8\%; R.pulchellus 0\%; and A.lepidum 28\%). Previous studies have reported positive correlations between $B$. burgdorferi prevelance and tick abundance [21]. However, the difference that we observed among our investigated areas was significant.

In our present work, we relied on the nested polymerase chain reaction ( $\mathrm{nPCR}$ ) in detection of Borrelia spp. where it is established that this technique is an excellent tool in increasing the specificity and sensitivity of pathogen detection, specifically when investigate samples from contaminated environments [22]. 
Our detection of Borrelia spp. was depending on OspA where it encodes an outer membrane protein which is a major antigen of the Lyme disease agent [23] to the extent that it is considering a promising candidate for an effective vaccine for Europe [23]. In addition to the Flagellin B (FlaB) gene. For ecological investigation and identification of the $B$. burgdorferis.l. species, the nPCR technique, and the FlaB and OspA gene targets, have been extensively used since the early 1990s, [24-27] and still used up till now [28, 29].

Studies employing PCR in Lyme disease diagnosis have yield variable results $[30,31]$. In our study, 350bp and 478 bpfragments corresponding to Borrelia $s p$. was amplified from investigated ticks (20.19\%). Our obtained data are consist with those ofprevious work and inconsist with others $[16,20,32,33]$.These discrepancies in the results may be attributed to different environmental factors as tick habitat, geographic distribution of reservoir hosts, developmental and/or feeding state of the investigated ticks or by different use of methods, particularly the sensitivity of the primers used and the PCR technique conditions. All these factors have strong impact on the obtained data [34]. In addition to, sitespecific ecological dissimilarity might elucidate the observed differences in collection rates in different studied areas. Continued collection will make clear the effects of local site variation, and on the degree to which ticks may be increasing in abundance, distribution, and transmit the infection.

Assessment of ticks for a range of bacterial agents has provided several additional associated factors. These findings deliver the highlights on the distributions and endemicity of emerging and potentially pathogenic tick-borne organisms. Some of these tick-borne agents may cause an unknown health risk. Given the wide distribution of these ticks, accurate assessments of the vectorial capacity, the frequency of the bacteria in these tick populations, their potential to

\section{REFERENCES}

[1] Morens, D.M., G.K. Folkers, and A.S. Fauci, The challenge of emerging and re-emerging infectious diseases. Nature, 2004. 430 (6996): 242. https://doi.org/10.1038/nature02759

[2] Parola, P. and D. Raoult, Ticks and tickborne bacterial diseases in humans: an emerging infectious threat. Clinical infectious diseases, 2001. 32: 897-928. https://doi.org/10.1086/319347

[3] Jongejan, F. and G. Uilenberg, The global importance of ticks. $\begin{array}{lllll}\text { Parasitology } & 129 & \text { (Suppl): } & \text { S3-S14. } & 2004 .\end{array}$ https://doi.org/10.1017/S0031182004005967

[4] Shapiro, E. and M. Gerber, Clinical infectious diseases. Clinical infectious diseases, 2000; 31: 533-42. https://doi.org/10.1086/313982

[5] Gupta, R.S., S. Mahmood, and M. Adeolu, A phylogenomic and molecular signature based approach for characterization of the phylum Spirochaetes and its major clades: proposal for a taxonomic revision of the phylum. Frontiers in microbiology, 2013. 4: 217. https://doi.org/10.3389/fmicb.2013.00322

[6] Barbour, A.G., Phylogeny of a relapsing fever Borrelia species transmitted by the hard tick Ixodes scapularis. Infection, Genetics and Evolution, 2014; 27: 551-558. https://doi.org/10.1016/j.meegid.2014.04.022

[7] Horak, I.G., J. Londt, and I. De Villiers, Parasites of domestic and wild animals in South Africa. XIII. The seasonal incidence of adult ticks (Acarina: Ixodidae) on cattle in the northern Transvaal. 1979. cause human and animal diseases, and their ability to act as competent vectors are warranted. Sustained study and monitoring will play a vital and crucial role in public health assessment for related disease threats.

Since the present knowledge on the ecology and epidemiology of different $B$. burgdorferi s.l. species is still inadequate. So, further information on the distribution of different $B$. burgdorferi s.l. species in their natural reservoir hosts and vectors is essentially needed [35].This is an fundamental prerequisite for a better understanding of borrelia spp. endemic circulation and also, for the establishment of effective preventive strategies against Lyme borreliosis..

In conclusion, the findings of this study provide additional information on the geographic distribution of $B$. burgdorferi in different ticks in Egypt. The overall frequency of B. burgdorferiin ticks (20.19\%) and animals (22.7\%).Shalateenarearecorded the highest incidence among the investigated localities.

Medical and veterinary professionals in Egypt should consider $B$. burgdorferias an emerging pathogen in the country. Future studies are needed to monitoringvectorial capacity of ticks in transmission B. burgdorferi to animals and humans in parallel with discovering other reservoir host animals and the vector competence of tick species for $B$. burgdorferi and its public health and economic significance in Egypt.

\section{Funding}

This study was funded by the research project No. 10120507 offered by National Research Centre, Egypt. In addition to, project No. 50/4/10 offered by Ministry of Higher Education and Scientific Research andoffered by desert research center, Egypt.

[8] Walker, A.R., Ticks of domestic animals in Africa: a guide to identification of species. 2003: Bioscience Reports Edinburgh.

[9] Doetsch, R., Determinative methods of light microscopy. Manual of methods for general bacteriology, 1981: p. 21-33.

[10] Motaleb, M.A., et al., Borrelia burgdorferi periplasmic flagella have both skeletal and motility functions. Proceedings of the National Academy of Sciences, 2000. 97: 10899-10904. https://doi.org/10.1073/pnas.200221797

[11] Rosa, P.A., K. Tilly, and P.E. Stewart, The burgeoning molecular genetics of the Lyme disease spirochaete. Nature Reviews Microbiology, 2005; 3: 129. https://doi.org/10.1038/nrmicro1086

[12] Kenedy, M.R., T.R .Lenhart, and D.R. Akins, The role of Borrelia burgdorferi outer surface proteins. FEMS Immunology \& Medical Microbiology, 2012. 66(1): p. 1-19. https://doi.org/10.1111/j.1574695X.2012.00980.x

[13] Otto, T., et al., ChromaPipe: a pipeline for analysis, quality control and management for a DNA sequencingfacility. 2008. https://doi.org/10.4238/vol7-3X-Meeting04

[14] Institute, S., Using JMP Student Edition for Windows and Macintosh: The User's Guide to Statistics with JMP Student Edition. 2009: SAS Institute.

[15] Snedeckor, G. and W.G. Cochran, Statistical Methods, Ed. 8. Ames, IA. 1989, lowa State University Press.

[16] Adham, F.K., et al., Detection of tick blood parasites in Egypt using PCR assay II-Borrelia burgdorferi sensu lato. J Egypt Soc Parasitol, 2010. 40: p. 553-564. 
[17] Abdel-Shafy, S., et al., Molecular detection of spotted fever group rickettsiae associated with ixodid ticks in Egypt. Vector-Borne and zoonotic diseases, 2012. 12(5): p. 346-359. https://doi.org/10.1089/vbz.2010.0241

[18] El, K.K., et al., Investigation of blood parasites in livestock infested with argasid and ixodid ticks in Egypt. Journal of the EgyptianSociety of Parasitology, 2001. 31(2): p. 365-371.

[19] McCoy, B.N., O. Maïga, and T.G. Schwan, Detection of Borrelia theileri in Rhipicephalus geigyi from Mali. Ticks and tick-borne diseases, 2014; 5: p. 401-403. https://doi.org/10.1016/j.ttbdis.2014.01.007

[20] Elhelw, R.A., M.I. El-Enbaawy, andA. Samir, Lyme borreliosis: A neglected zoonosis in Egypt. Acta tropica, 2014; 140: 188-192. https://doi.org/10.1016/j.actatropica.2014.09.005

[21] Williams, S.C., et al., Managing Japanese barberry (Ranunculales: Berberidaceae) infestations reduces blacklegged tick (Acari: Ixodidae) abundance and infection prevalence with Borrelia burgdorferi (Spirochaetales: Spirochaetaceae). Environmental entomology, 2009. 38(4): p. 977-984. https://doi.org/10.1603/022.038.0404

[22] Melničáková, J., M. Derdáková, and I. Barák, A system to simultaneously detect tick-borne pathogens based on the variability of the $16 \mathrm{~S}$ ribosomal genes. Parasites \& vectors, 2013. 6(1): p. 269. https://doi.org/10.1186/1756-3305-6-269

[23] Dunn, J.J., B.N. Lade, and A.G. Barbour, Outer surface protein A (OspA) from the Lyme disease spirochete, Borrelia burgdorferi: high level expression and purification of a solublerecombinant form of OspA. Protein expression and purification, 1990. 1(2): p. 159-168. https://doi.org/10.1016/1046-5928(90)90011-M

[24] Lenčáková, D., et al., Prevalence of Borrelia burgdorferi sl OspA types in Ixodes ricinus ticks from selected localities in Slovakia and Poland. International Journal of Medical Microbiology, 2006. 296: p. 108-118. https://doi.org/10.1016/j.ijmm.2005.12.012

[25] Wise, D.J. and T.L. Weaver, Detection of the Lyme disease bacterium, Borrelia burgdorferi, by using the polymerase chain reaction and a nonradioisotopic gene probe. Journal of clinical microbiology .1991 ,

:(7)29p. 1523-1526. https://doi.org/10.1128/JCM.29.7.15231526.1991

[26] Johnson, B.J., et al., Detection of Borrelia burgdorferi in ticks by speciesspecific amplification of the flagellin gene. The American journal of tropical medicine and hygiene, 1992. 47(6): p. 730-741. https://doi.org/10.4269/ajtmh.1992.47.730
[27] Schmidt, B., PCRin laboratory diagnosis of human Borrelia burgdorferi infections. Clinical microbiology reviews, 1997. 10(1): p. 185-201. https://doi.org/10.1128/CMR.10.1.185

[28] Nolte, O., Nucleic Acid Amplification Based Diagnostic of Lyme (Neuro) borreliosis-Lost in the Jungle of Methods, Targets, and Assays? The open neurology journal. 2012; 6: 129-39. Epub 2012/12/12. https://doi. org/10.2174/1874205X01206010129 PMID: 23230454. https://doi.org/10.2174/1874205X01206010129

[29] Wills, M.K., A.M. Kirby, and V.K. Lloyd, Detecting the Lyme Disease Spirochete, Borrelia Burgdorferi, in Ticks Using Nested PCR. JoVE (Journal of Visualized Experiments), 2018(132): p. e56471. https://doi.org/10.3791/56471

[30] Cerar, T., et al., Comparison of PCR methods and culture for the detection of Borrelia spp. in patients with erythema migrans. Clinical Microbiology and Infection, 2008. 14(7): p.658-653 https://doi.org/10.1111/j.1469-0691.2008.02013.x

[31] van Dam, A.P., Molecular diagnosis of Borrelia bacteria for the diagnosis of Lyme disease. Expert opinion on medical diagnostics, 2011. 5(2): p. 135-149. https://doi.org/10.1517/17530059.2011.555396

[32] Barghash, S., et al., Molecular detection of pathogens in ticks infesting camels inMatrouh Governorate, Egypt. J Bacteriol Parasitol, 2016. 7(259): p. 2. https://doi.org/10.4172/2155-9597.1000269

[33] Hassan M. I., H.s.M.G., Abdel-shafy S. , Hammad K. M. and Mokhtar M. M., Molecular detection ofBorrelia sp.InOrnithodorossavignyiandRhipicephalus annulatusby flab gene andBabesiabigeminain R. annulatusby 18s rRNA gene. J. Egypt. Soc. Parasitol. (JESP) 2017. 47(2): p. $403-414$.

[34] Kim, E.-J., et al., Improved PCR/nested PCR approaches with increased sensitivity and specificity for the detection of pathogens in hard ticks. Ticksand tick-borne diseases, 2013. 4(5): p. 409-416. https://doi.org/10.1016/j.ttbdis.2013.04.004

[35] Michel, H., et al., An ospA-polymerase chain reaction/restriction fragment length polymorphism-based method for sensitive detection and reliable differentiation of all European Borrelia burgdorferi sensu lato species and OspA types. Medical microbiology and immunology, 2004. 193(4): p. 219-226. https://doi.org/10.1007/s00430-003-0196-8 